\title{
Co-operation with the Geological Survey Department of Ghana
}

\author{
Feiko Kalsbeek, Bjørn Hermansen, Christian Knudsen, Leif Thorning and Marianne Thorsen
}

Between October 2001 and the end of 2003 there was a close co-operation between the Geological Survey of Denmark and Greenland (GEUS) and the Geological Survey Department of Ghana (GSD), as part of a project to enhance GSD's institutional capabilities and effectiveness, mainly in the fields of management, geological mapping, map production and data handling. During this period a team of geologists, GIS (Geographic Information System) and database experts as well as administrative staff from GEUS have visited GSD, and GSD officers have visited GEUS in Copenhagen.

The main obstacles to GSD becoming an effective organisation are its status as a department under the Ghana Ministry of Mines, insufficient funding by the government, and poor remuneration of its professional staff. To overcome these obstacles, attempts are being made to change the status of GSD from a 'civil servant organisation' into a semiautonomous institution, which will permit the Survey to generate funding for its core activities by providing services to outside organisations, and pay better salaries to its personnel.

Despite many problems, geological mapping has been resumed and three new geological maps have been produced by GSD during the project and stored in GIS format. A mapping manual has been prepared, and the structure and 'Mission and Vision Statements' for the Survey have been revised.

\section{Geology and mineral resources}

Ghana lies in West Africa, at between $5^{\circ}$ and $11^{\circ}$ north of the Equator (Fig. 1). It has a surface area of c. $240000 \mathrm{~km}^{2}$ and c. 20 million inhabitants. Its main export commodities are gold, cocoa and timber. Apart from gold, Ghana hosts major occurrences of manganese, bauxite, diamonds and other raw materials.

Most of western and northern Ghana is underlain by Palaeoproterozoic, isoclinally folded, metabasaltic and metasedimentary rocks of the 'Birimian Supergroup' (age -2.2 Ga; Taylor et al. 1992; Hirdes \& Davis 1998). The metabasalts (Fig. 2) form a number of NE-SW-trending volcanic belts, separated by metasedimentary basins (Fig. 1; Kesse 1985; Leube et al. 1990). A slightly younger, unconformable unit of sandstones and conglomerates, the 'Tark-waian Group', overlies the Birimian volcanic rocks (Fig. 1). Rocks of the

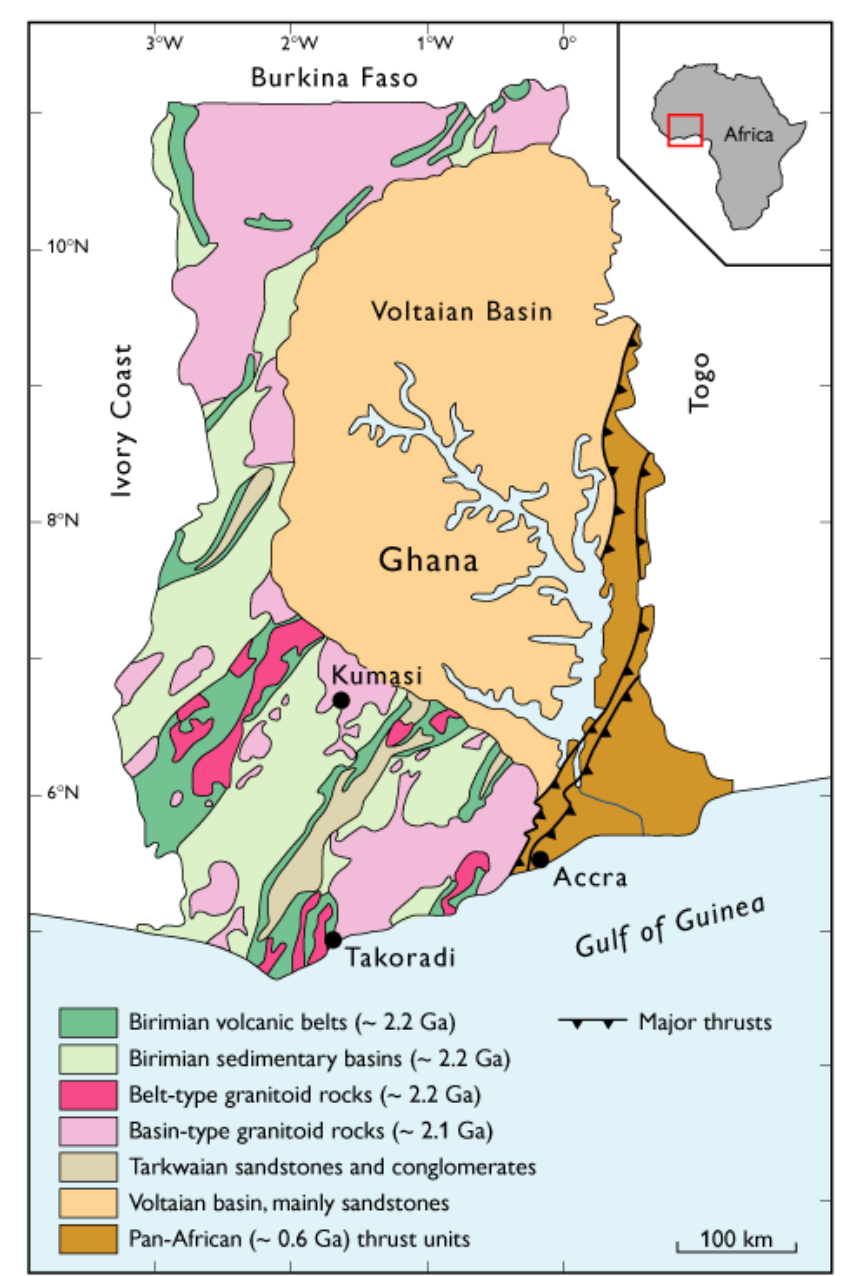

Fig. 1. Simplified geological map of Ghana, modified from Kesse (1985). Granitoid rocks are subdivided into c. $2.2 \mathrm{Ga}$ 'Belt-type granites' and c. 2.1 Ga 'Basin-type granites', which are mineralogically and chemically distinct (Hirdes et al. 1992).

Birimian Supergroup are cut by numerous granitoid intrusions (Fig. 3), which have yielded ages of 2.2-2.1 Ga (Hirdes et al. 1992). Most of Ghana's mineral deposits are associated with Birimian supracrustal rocks; gold also occurs within Tarkwaian conglomerates.

The central part of the country is occupied by a thick succession of undeformed Neoproterozoic to Early Palaeozoic sedimentary rocks, mainly sandstones (the 'Voltaian basin'), 


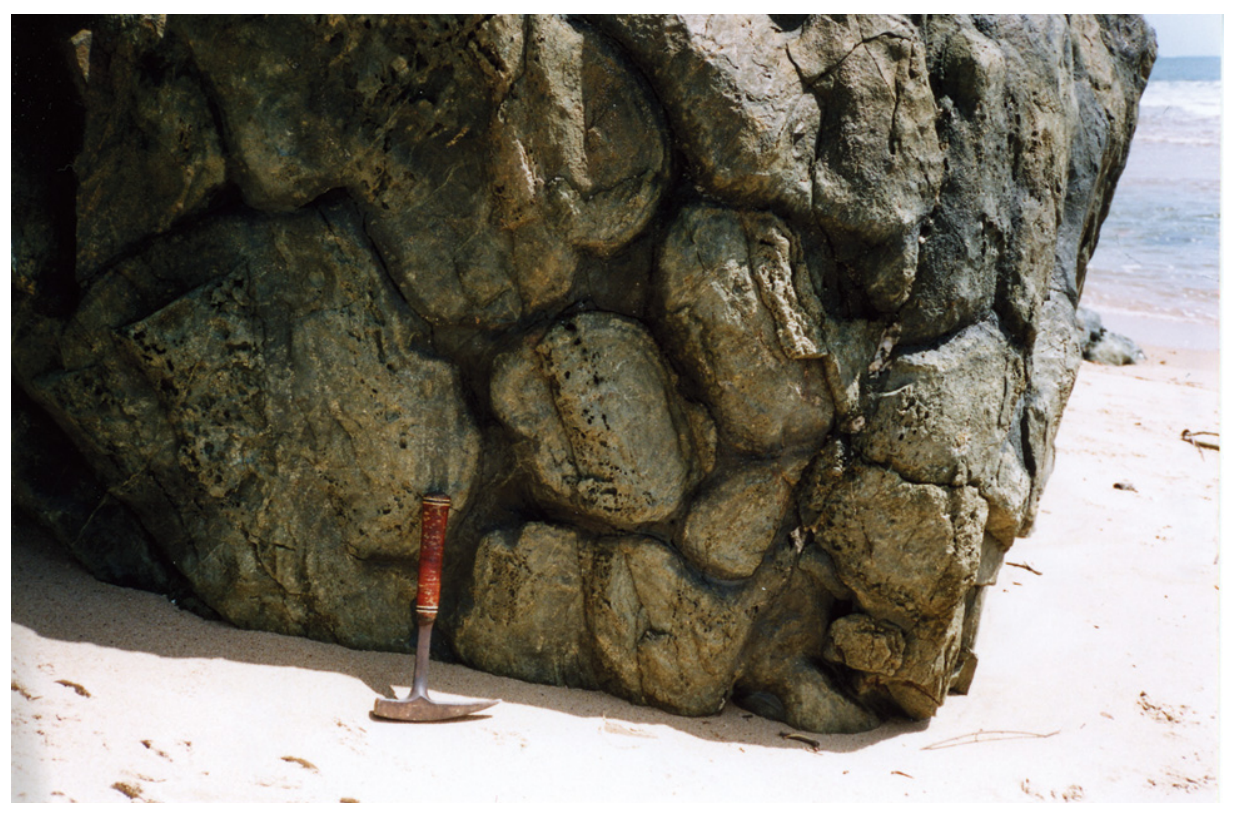

Fig. 2. Pillow lava at Butre, a coastal village west of Takoradi. Hammer for scale.

which have not been studied in detail. The eastern part of the country consists of a number of thrust sheets composed of sedimentary and crystalline rocks, the ages of which are not well known. They were emplaced during the pan-African orogenic cycle - $600 \mathrm{Ma}$ ago (Hirdes \& Davis 2002).

Along the coast and offshore a succession of Palaeozoic and Mesozoic sedimentary rocks occurs, and there is a limited offshore production of hydrocarbons.

\section{The Geological Survey Department of Ghana and GEUS' involvement}

The Geological Survey Department of Ghana was established in 1913 as the 'Gold Coast Geological Survey'. Through the years it has made major contributions to the understanding of the geology of the country, forming the basis for exploration and exploitation of the mineral resources. Geological mapping before the Second World War was restricted mainly to regional studies, and the first geological map at 1:1000 000 was published in 1955. After gaining independence in 1957, the new Ghana government invested much energy in the Survey in order to boost the mineral industry, and during the 1960s and 1970s large parts of the country were geologically mapped in more detail. In the beginning the Survey was supported by a number of geologists from the former Soviet Union, but this co-operation was brought to an end for political reasons. Since the early 1980s GSD has been supported in several projects by the German Bundesanstalt für Geowissenschaften und Rohstoffe (BGR). Nevertheless, mainly as the result of economic starvation, the activities of the Survey during the last few decades have gradually dimi- nished. Equipment could not be maintained, qualified staff left, and ultimately the Survey was no longer able to perform many of its natural duties.

During the late 1990s the Ghana government decided that GSD should be gradually reconstructed and upgraded in order to improve its effectiveness. This process has been supported by the World Bank, through a loan from the Nordic Development Fund. GEUS was selected to help with the reconstruction of GSD under a contract with the Minerals Commission of Ghana (NDF Credit 156-14). The project ran from 1 October 2001 to 31 December 2003, and the contract sum was $c$. $€ 350000$.

\section{Aims of the project}

The main topics to be addressed during the project were:

1. Formulation of new 'Mission and Vision Statements'.

2. Development of a new organisational structure.

3. Reorganisation of the Survey's Division for Geological Mapping, including the preparation of a GSD mapping manual.

4. Upgrading the Survey's capability to handle digital data and provide information in digital form.

5. Supporting the Survey's programme of Human Resources Development.

Several of these topics had been initiated by GSD before the beginning of its co-operation with GEUS. 


\section{Approach}

The original plan for the project was that a consultant should provide the Survey with a single adviser. In GEUS' bid for the project, however, it was suggested that, instead of providing one adviser, a team should be formed to support the Survey, consisting of a team leader, who would spend about half of the time in Ghana, and a number of short-time specialists would make periodic visits. In this way it was thought that GEUS would be able to provide support in a number of subjects which could not be covered by one single person. Permission was later obtained for GSD officers to visit GEUS in Copenhagen for shorter periods, instead of GEUS officers visiting Ghana.

An Inception Report was prepared jointly by GEUS and GSD in December 2001 to outline further plans for the project. Progress Reports were prepared for each of the four following half-year periods, including Mission Reports on each visit made. In December 2003 a draft Final Report was submitted.

\section{GSD's formal status}

GSD is at present a Department under the Ghana Ministry of Mines. This has a number of consequences that impede the development of the Survey as an effective organisation:

1. Governmental funding is insufficient.

2. Salaries are very low, as the staff are employed as public servants. Young geologists have difficulties in supporting their families and will leave for better paid jobs as soon as possible. As a result of low salaries, poor funding and lack of other incentives, the level of job satisfaction is low.

3. As a Ministerial Department the Survey has to follow strict rules for promotion of its personnel. Seniority plays a far greater role in this process than qualifications and performance.

4. Dismissal of redundant personnel is virtually impossible under the present situation. The Survey has some 300 employees, far more than can be kept usefully occupied with the available funding.

The problems for GSD imposed by its status as a Ministerial Department have been recognised by the government and, with legal advice from GEUS, a new 'Geological Survey Act' has been prepared and submitted to the Ministry of Mines for further consideration. This act, if and when accepted by the Ghana Parliament, will transform the Survey into a semiautonomous organisation, which will be able to generate funding for its core activities by providing services to outside organisations. Moreover, the Survey will have the possibility

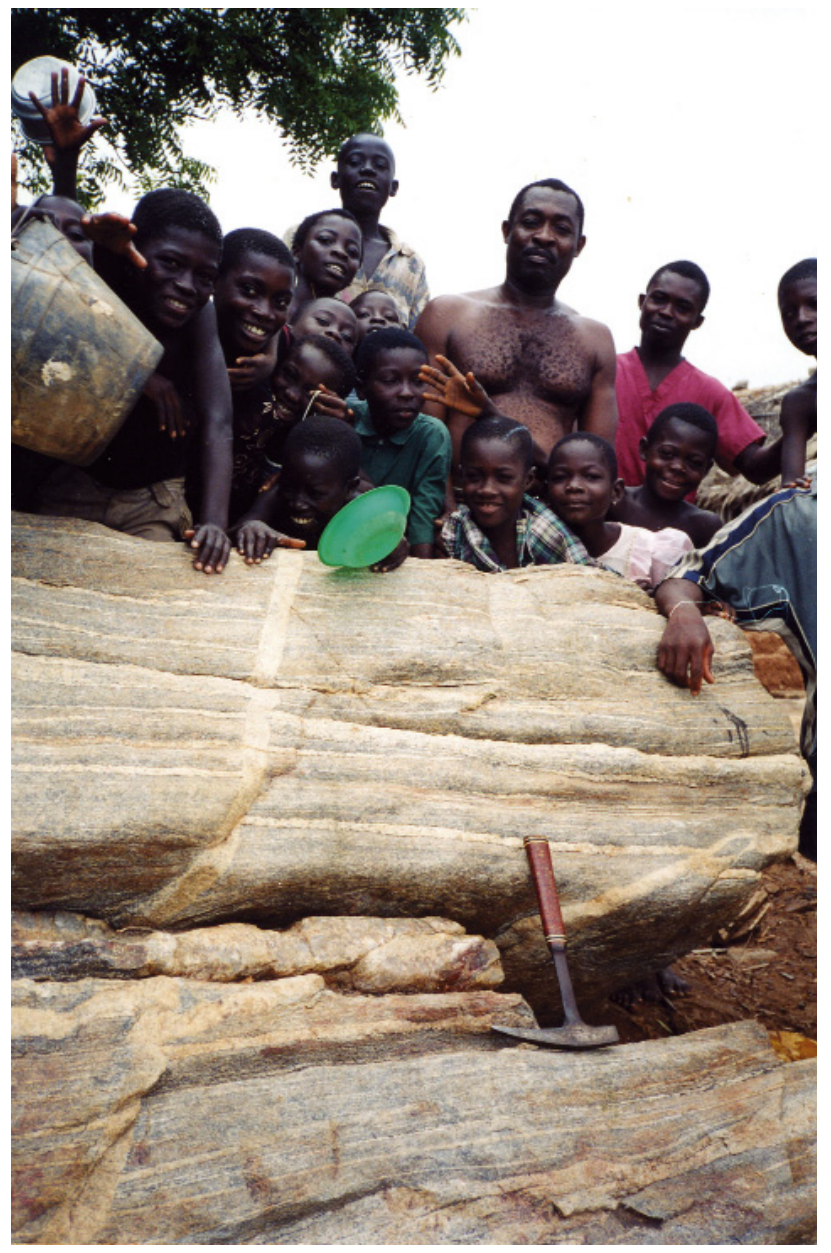

Fig. 3. Strongly deformed granitoid gneisses at Abuesi, a coastal village west of Takoradi. The gneiss has been dated at c. $2180 \mathrm{Ma}$ (zircon U- pb); a granitic vein has yielded zircon and monazite U-Pb ages of c. $2100 \mathrm{Ma}$ (D.W. Davis in Loh \& Hirdes 1999).

of adjusting the number of staff employed to its actual needs. In a close co-operation between GSD and GEUS, 'Mission and Vision Statements' for this new organisation were formulated, and an organisational structure suggested.

\section{Main achievements during the project}

Lack of sufficient funding for field work etc. has severely limited the success of the project. Nevertheless, with GEUS support, GSD has made significant progress, especially in the fields of geological mapping, GIS applications, database issues and human resources development.

\section{Geological mapping}

At the beginning of the present project, geological mapping had been started in five areas in Ghana. Four of these map- 
ping projects were completed by June 2002, and new geological maps were produced. Mapping in one area could not be concluded; this is an area in eastern Ghana consisting of supracrustal rocks that require experience in stratigraphy and sedimentology, at that time not available at GSD.

All mapping teams were visited in the field. Most of the geologists responsible for the mapping do an excellent job. However, most of the junior (assistant) geologists need more training before they will be able to carry out independent mapping projects.

Compilation of the new geological maps (1:100 000) was carried out in Accra. Thin sections and chemical analyses prepared by GEUS were used for the correct identification of the various rock types. The final maps were prepared by the staff of GSD's GIS laboratory with support from GEUS. This was the first time that new GIS geological maps have been produced at the Survey.

\section{Digitising old geological maps and reports}

In order to save old geological maps in GSD's archives from deterioration, digitising of existing maps has had a high priority during the project. A database was made with information on all existing maps. GEUS helped train GSD staff in the application of GIS in map production. Fourteen old maps were digitised during the project period, and a CDROM with these maps has been prepared. This has been one of the most successful parts of the project.

\section{Databases}

Since there is an urgent need for GSD to be able to present its data to the public in the form of databases, a major effort has been made to upgrade the Survey's experience in this field. GEUS has analysed which databases would be most needed and, in order to improve the understanding of database issues at GSD, a Minerals Occurrence Database has been established.

\section{Human Resources Development}

Continuous training of its staff as well as recruitment of skilled young geologists will be necessary for GSD to become a strong and professional Geological Survey. In this context major parts of GEUS' efforts under the project have been directed to practical on-the-job training of GSD personnel. Apart from training related to geological mapping, GIS and databases described above, GEUS has provided a collection of thin sections with descriptions of typical Greenland rocks, given courses in the microscopic study and classification of rocks, provided training in geological mapping for two GSD geologists as participants in GEUS' 2002 mapping project in Greenland, sponsored an excursion for a group of GSD geologists in the Western and Central Regions of Ghana, and conducted a training course for GSD's management on internal co-operation and related issues.

\section{Sustainability}

There is no doubt that co-operation with GEUS has improved the ability of GSD to carry out several of its main functions. However, for these improvements to be sustainable in the future, it is imperative that the Survey is changed into a semi-autonomous organisation. Only then will the Survey have the possibility to generate income to cover parts of its running expenses. Moreover, it would be able to adapt the number of staff to its actual needs and provide better wages for its remaining personnel, thereby improving job satisfaction and limiting the number of well-qualified staff that leave the organisation.

\section{References}

Hirdes, W. \& Davis, D.W. 1998: First U-Pb zircon age of extrusive volcanism in the Birimian Supergroup of Ghana/West Africa. Journal of African Earth Sciences 27, 291-294

Hirdes, W. \& Davis, D.W. 2002: U-Pb zircon and rutile metamorphic ages of Dahomeyan garnet-hornblende gneisses in southeastern Ghana, West Africa. Journal of African Earth Sciences 35, 445-449.

Hirdes, W., Davis, D.W. \& Eisenlohr, B.N. 1992: Reassessment of Proterozoic granitoid ages in Ghana on the basis of $\mathrm{U} / \mathrm{Pb}$ zircon and monazite dating. Precambrian Research 56, 89-96.

Kesse, G.O. 1985: The mineral and rock resources of Ghana. xiv +610 pp. Rotterdam: Balkema.

Leube, A., Hirdes, W., Mauer, R. \& Kesse, G.O. 1990: The Early Proterozoic Birimian Supergroup of Ghana and some aspects of its associated gold mineralization. Precambrian Research 46, 139-165.

Loh, G. \& Hirdes, W. 1999: Explanatory notes for the geological map of Southwest Ghana 1:100,000 Sekondi (0402A) and Axim (0403B) sheets. With contributions from C. Anani, D.W. Davis and U.K. Vetter. Geologisches Jahrbuch Reihe B. Heft 93, 149 pp. + 2 maps.

Taylor, P.N., Moorbath, S., Leube, A. \& Hirdes, W. 1992: Early Proterozoic crustal evolution in the Birimian of Ghana: constraints from geochronology and isotope geology. Precambrian Research $\mathbf{5 6}$ 97-111. 